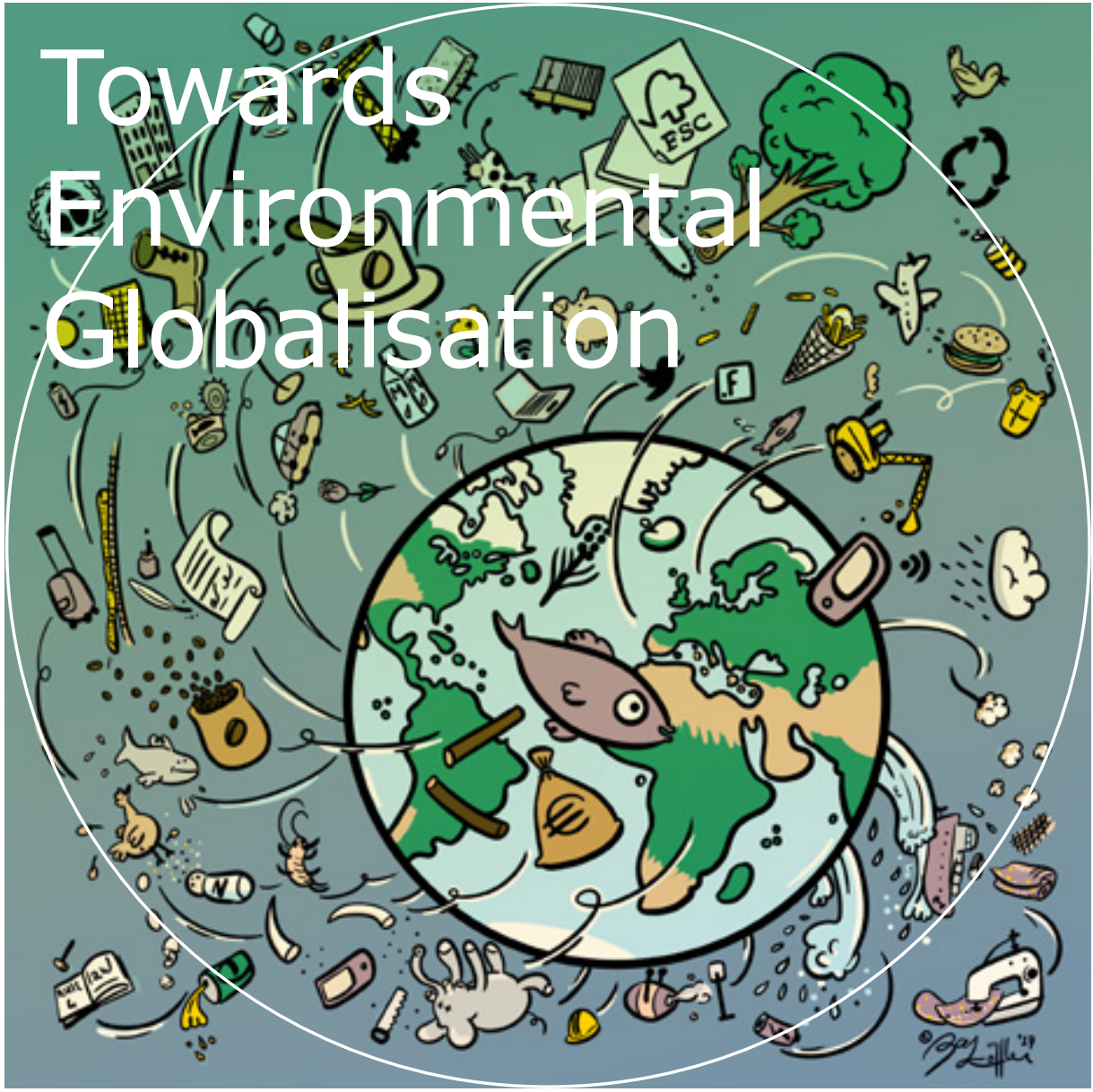

Prof.dr Simon R. Bush

Inaugural lecture upon taking up the position of Professor of

Environmental Policy at Wageningen University \& Research on

7 September 2017 



\section{Towards Environmental Globalisation}

Prof.dr Simon R. Bush

Inaugural lecture upon taking up the position of Professor of Environmental Policy at Wageningen University \& Research on 7 September 2017 
DOI HTTPS://DOI.ORG/10.18174/440790 ISBN 978-94-6343-256-6 


\section{Towards Environmental Globalisation}

Esteemed Rector Magnificus, dear colleagues, students, family and friends,

\section{The global environment through a fish eye lens}

As a group of species, tuna is among the most globalised organisms on the planet.

Tuna are not only biologically impressive for the tens of thousands of kilometres they travel each year, they're also some of the most delicious and therefore highly valued food products on the planet. This means they're subject to the fantasies of food consumers as much as the practicalities of industrial and small scale fishers using a diversity of gears around the world.

Like so many environmental problems, the sustainability of tuna starts with social scientific questions. Can consumers change their shopping and cooking practices to drive sustainability? What kinds of incentives can be delivered to fishers for investing in sustainable production practices? How can private standards, like the Marine Stewardship Council, push governments to regulate where, when and how tuna are removed from our oceans? Answering these questions starts with an understanding of the global linkages that exist between diverse groups of people pushing a broad sustainability agenda. An agenda that includes food security, safety and quality, social wellbeing and the ongoing health of ocean ecosystems.

Let me illustrate how these various dimensions come together. Decisions on sustainable fishing requires cooperation between more than 100 governments participating to varying degrees in the five tuna regional fisheries management organisations (Allen et al., 2010). Not only do these countries define fishing activity, they also negotiate access rights to, and benefits from, the exploitation of tuna. Who gets how much of what?

The negotiations are also uneven. Established distant water fishing nations, including the US and EU member states, representing large multi-national corporations, negotiate with small island states that depend on tuna for up to $70 \%$ of their gross 
domestic product (Havice, 2010; Bailey et al., 2012). This means tuna fisheries are more than only the accumulation of wealth. They are fundamental to securing local livelihoods and food security in poor island nations, as well as contributing to nutrition security in more than 100 markets around the world (Mullon et al., 2017).

In short, tuna is not only impressive because it is one of the most biologically dynamic fish in the sea, but also because it is the most globalised.

My keen interest in tuna, and more generally fisheries and aquaculture, does not mean that the Environmental Policy Group will become the 'Fisheries Policy Group'. Far from it. What my 'fish eye lens' does enable me to do is to question, illustrate and confront the global challenge of governing environmental sustainability transitions under conditions of globalisation.

To realise this we first have to consider what globalisation is and what it is not. While globalisation has made the headlines over the last years it has done so because of a lack of understanding of its close relative globalism. Whereas globalisation is a descriptor for ongoing processes of social change at the global scale, globalism is, in the words of Ulrich Beck, "the view that the world market eliminates or supplants political action - that is, the ideology of rule by the world market, the ideology of neo-liberalism" (Beck, 2015, p.9).

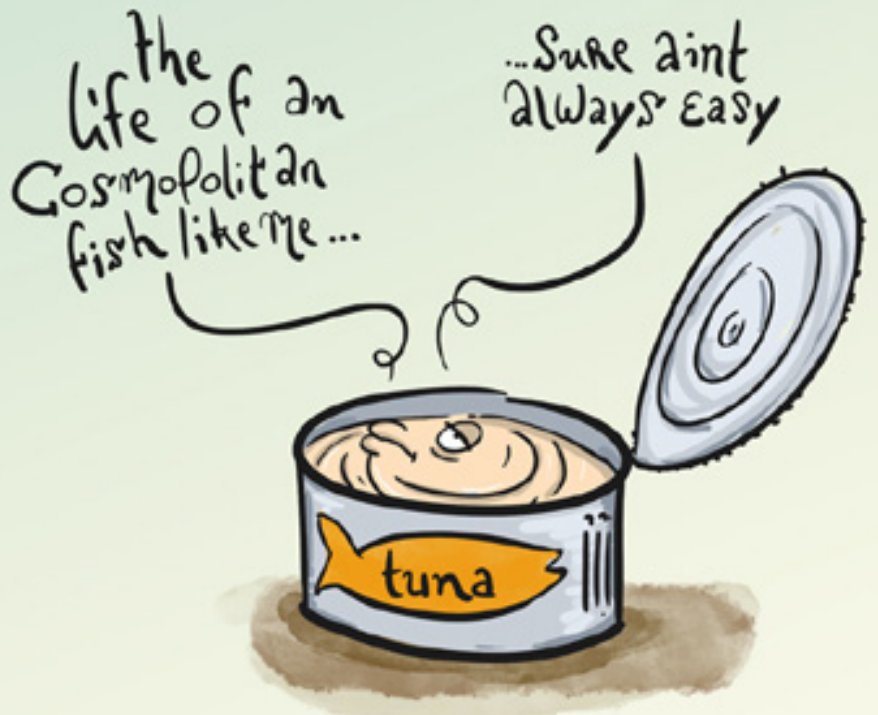

Tuna, the globally cosmopolitan fish 
For tuna, globalism is the political economic project of capital accumulation that has led to the control of the world's canning sector by six multinational companies (Havice and Campling, 2017). Central to their strategy is to maintain high volume, low value supply to major export markets. In doing so these firms transcend national borders, avoid regulation and ultimately hold the potential undermine the very resource on which they depend.

But from a perspective of globalisation, as a process of social change, alternative interpretations of the tuna emerge. Global concern over the sustainability of tuna has led to the emergence of what has been labelled as 'governance innovation networks' (Miller, 2014), comprised of civil society, tuna firms, and fishing and coastal states, partnering with and agitating the industry to take on a range of reforms. Through this lens the thesis of 'unrestrained capitalism' is but one interpretation of how the tuna industry is structured. Central to my argument today is that this thesis is also one that limits the potential for social science to contribute to the re-design of sustainable production and consumption. The question for social science groups like the environmental policy group is then whether we can go beyond critiques of globalism to identify a form of globalisation as a process of governing environmental change.

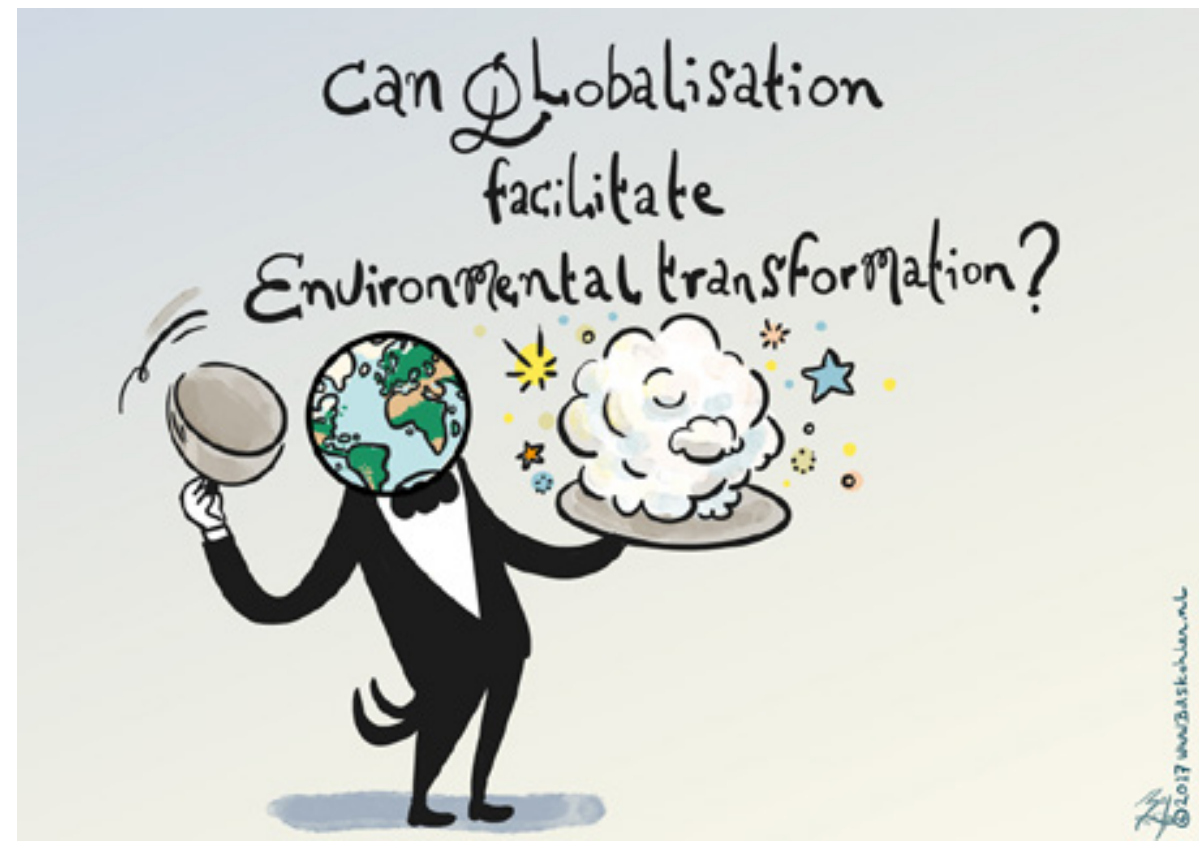

Globalisation's role in environmental transformations 
For tuna, like other globally interconnected industries, this means identifying new modes of governing sustainable production, trade and consumption. It also means asking how and to what extent new environmental governance arrangements, both public and private, can be reflexively designed by a wider range of societal actors. Seen as such, the challenges of governing the sustainability of tuna represents many aspects of the future research agenda of our group.

In elaborating on this agenda, I will first provide a brief outline of globalism as a narrow form of economic and political globalisation, thereby discussing in some detail the limitations of thinking that neoliberal capitalism is a near unstoppable driving force of environmental degradation. I will then argue for an alternative 'environmental globalization', conceived as a reflexive mode of social transformation across geographical scales. Following this line of argumentation I will then outline a research agenda for the Environmental Policy Group moving forward.

\section{Economic and political globalism}

The historian Francis Fukuyama referred to globalism as an agenda of Western liberal democracies in the aftermath of the Second World War to control the global economic order. The consequence of this global order being a rationalisation and convergence of societal norms and values everywhere. As Fukuyama put it - the 'end of history' (1992). Globalism has also been associated with a new geological era labelled the 'anthropocene'; characterised by globally linked flows of capital that extend the capacity of humans to exploit the earth at an intensity that outstrips the 'great forces of nature' (Steffen et al., 2007). But while offering a powerful set of metaphors, I argue that this view of globalism, and by extension globalisation, is a narrowly framed apocalyptic vision of environmental degradation and social inequality.

Globalism is also related to what Beck labels 'simple' modernisation, which refers to processes of instrumental rationality, technological industrialisation, and economically driven processes of social change (Beck, 1992). Simple modernisation, linked to capitalism, is thought to underpin modes of production and consumption that creates distance and therefore societal apathy to environmental degradation. It is also linked to processes of global re-scaling, restructuring and privatisation to enhance the mobility of capital around the globe (Newell and Paterson, 2010; Peet et al., 2010; Newell, 2012). It is this combination of modernisation and neoliberal capitalism that underscores the assumption that globalisation is the main driver and intensifier of global environmental degradation and social inequality. 


\section{Economic andpolitical globalism}

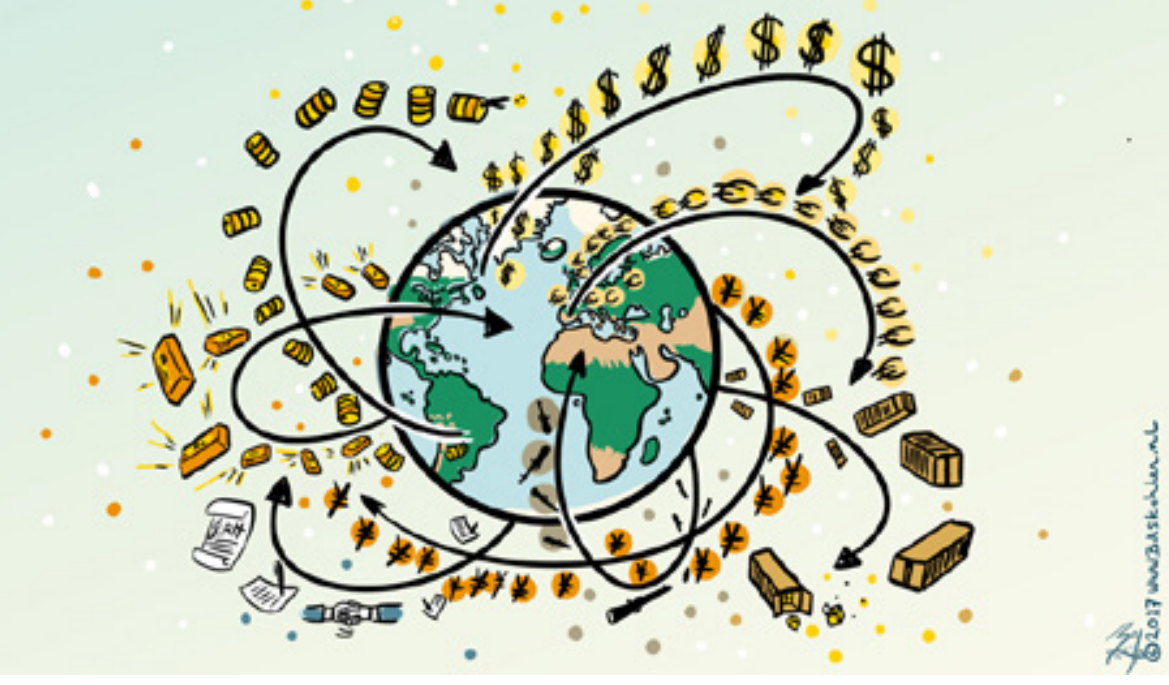

Economic and political globalism

The result is that global markets are seen as an uncontrollable force that can undermine, eliminate or supplant political action. The well-worn argument is that faced with fleet-of-foot capital flows, nation states are disciplined into tailoring their economies and as such legislation to not only attract capital but also to ensure that capital does not slip beyond their borders (see for example Porter, 1990); a so called 'race to the bottom'. The Bretton Woods institutions and the World Trade Organisation, together adjust national political economies to enable these capital flows. The result is an erosion of the sovereignty of the nation state. As argued by Manuel Castells (1996), the more states try to intervene in controlling these flows, the less they come to represent the sovereign interests of the societies they represent.

Through this narrow lens of neoliberal globalism environmental protection is limited to the same market and financial institutions that structure the global economic order (Bernstein, 2002). Environment protection through the market is then a further process of capital accumulation. For example, 'green grabbing' or the appropriation of the resources from communities for global environmental ends (e.g. Fairhead et al., 2012). Here we can think of the expulsion of communities from forests that are now valued more as global carbon sinks than as local economic and cultural 

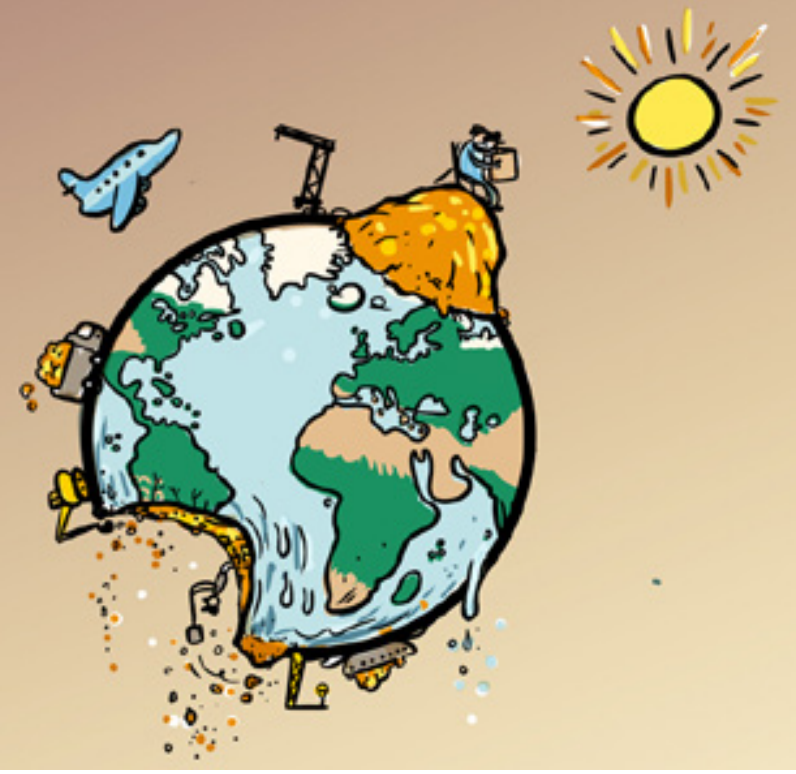

Global markets as an uncontrollable force

resources (e.g Corbera et al., 2007). We can also think of the impacts of ecocertification for coffee, fish or palm oil giving market incentives to producers who pass audits, but not necessarily to change their practices for material environmental gains (Darnall and Sides, 2008).

I argue that while there is certainly evidence to demonstrate these impacts, including the work of myself and my students on aquaculture in Southeast Asia (e.g. Anh et al., 2011; Ha et al., 2012; Bush et al., 2013), a singular attribution of environmental degradation to neoliberal globalism suffers from the same homogenising trap it seeks to address. This is because globalism risks feeding into a narrative of there being 'no alternative', which in turn risks devoiding societal actors of their agency to address environmental degradation. A further danger is that while we struggle to understand the impacts of Western globalism, we may be missing the emergence of alternative forms of globalization that better suit the contemporary settings of increasing global interdependency to tackle global environmental reform (Mol, 2001). In fact, neoliberalism is just one mode of de-regulation and sub-sequent re-regulation that has emerged since 1980 . 
At the dawn of the Asian Century we need to give greater attention to understanding the role that regulated market economies are also playing in addressing global issues such as the environment. China is the obvious contender having recently taken their domestic environmental ambitions to the global stage - perhaps in the future even surpassing the US and EU (Carter and Mol, 2006; He et al., 2012). In other major Asian economies such as Thailand, Vietnam and India globalisation is also playing out in different ways and with different environmental outcomes (see for example Ha and Bush, 2010; Vijge and Gupta, 2014; Thongplew et al., 2016; Simpson and Smits, 2018). Take the emergence of regional carbon markets, the emergence of sustainable food movements, sustainable energy transitions, and private sector climate initiatives. While far from perfect, these initiatives often represent mixtures of local and regional actors and institutions rather than only the global market.

By opening up globalisation to rationalities that go beyond neoliberal capitalism alone we can start to dispel the myth that there is 'no alternative', or that we have indeed reached the 'end of history'. Doing so can overcome the tight connection between globalisation and neoliberalism. It also consequently allows us to move beyond a narrow band of singular governance strategies, such as strengthening the

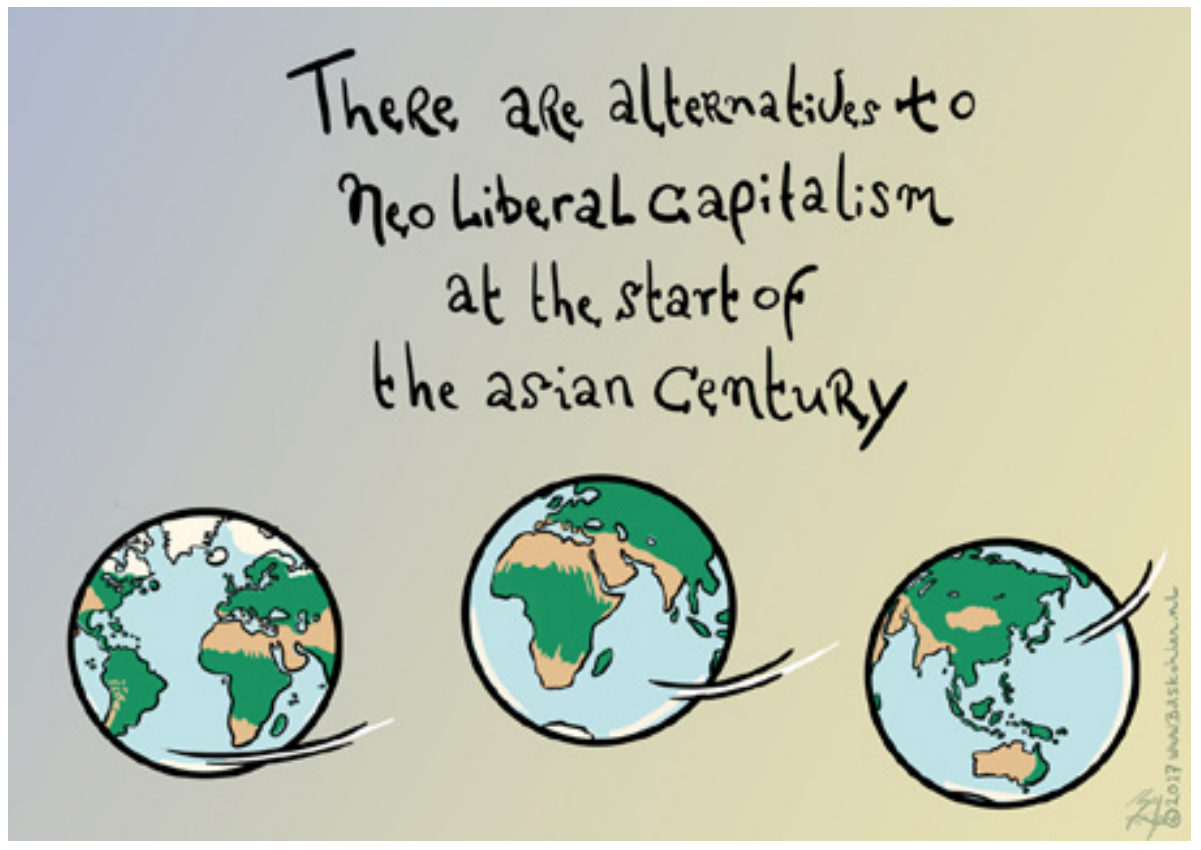

Neoliberalism in the Asian Century 
role of the state, increasing domestic control of trade and investment, and preventing privatisation (Mol, 2001). It instead allows us to identify alternative solutions to tackle global environmental reform under conditions of increasing global interconnectivity.

The social sciences at Wageningen are well placed to do this. In fact I argue we have an obligation to contribute knowledge on how global social, political and economic relations can shape positive environmental transformations. We can achieve this by recognising that globalisation is made up of day-to day activities that are influenced by events happening on the other side of the globe, as well as constituted by the practices and decisions of local communities that can lead to significant global change. In short, we need to demonstrate that globalisation is not an immovable force, but a malleable set of practices, institutions and relations that exert action at a distance.

\section{Environmental globalisation}

The question is then whether it is possible to steer positive environment outcomes through globalisation? While there is a rich literature outlining the 'one world, many globalisations' thesis, most scholars have limited the scope of research to economy, culture and politics. Environment is reduced to a cross cutting issue, influenced by these three domains. However, I ague that if we put environment as a fourth pillar of globalisation we can observe what I label an 'environmental globalisation', characterised by globally inter-connected social practices, institutions and relations that not only exploit but also conserve a range of biological and biophysical resources. Building on the work of Held and McGrew (2007) four key characteristics of globalisation are instructive for understanding the social nature of the global environment.

First, there is a stretching of the environment in both material and social terms across political frontiers. While it is also true that not all environmental problems are global in nature, it is clear that in a variety of sectors and domains environments and environmental concerns extend far from, through and beyond localities or single nation states. Tuna is a case in point, swimming across national borders, between socio-cultural regions and internationally established fishery management organisations. The sustainability of these fish is only possible if there is international cooperation between the coastal states in whose waters tuna are caught, with fishing states who control the fishing vessels and increasingly the 'market states' that shape demand for tuna (Adolf et al., 2016; Havice and Campling, 2017). The same of course goes for green-house gas emissions, phosphates and biodiversity (Turnhout and 


\section{Stretching of the Endirongent}
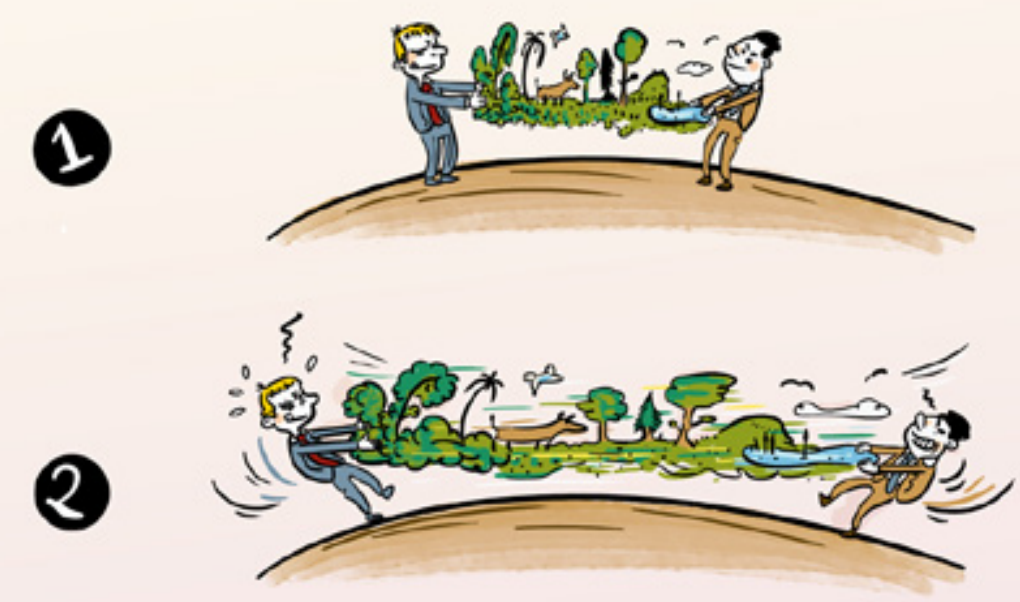

Stretching of the environment

Boonman-Berson, 2011; Oosterveer and Sonnenfeld, 2012). In other cases environments are globalised through the agency of consumers. Take tourism for example (van Bets et al., 2016). Exceptional sites of beauty such as Chile's Patagonia or the city of Amsterdam are stretched across borders through experiential forms of consumption - either by those that are visiting or those that place demands on the conservation of these environments.

Second, there is a growing intensification of social and material interconnectedness in the use of the environment and in response to environmental degradation. Again Tuna is illustrative. New technologies have facilitated information exchange along tuna value chains to enable consumers to see where tuna is caught, how and by who. Research with small scale fishermen in Indonesia and the Philippines has shown how US and EU buyers and NGOs work directly with communities to develop transparent and sustainable fishing practices (e.g Duggan and Kochen, 2016; Tolentino-Zondervan et al., 2016; Bush et al., 2017). These same buyers and NGOs create linkages with consumers right here in the Netherlands, in turn creating pressure on the Marine Stewardship Council, the Dutch government and European Union alike to institute regulations that directly affect the sustainability and 


\section{intensification of the Endironment by...}

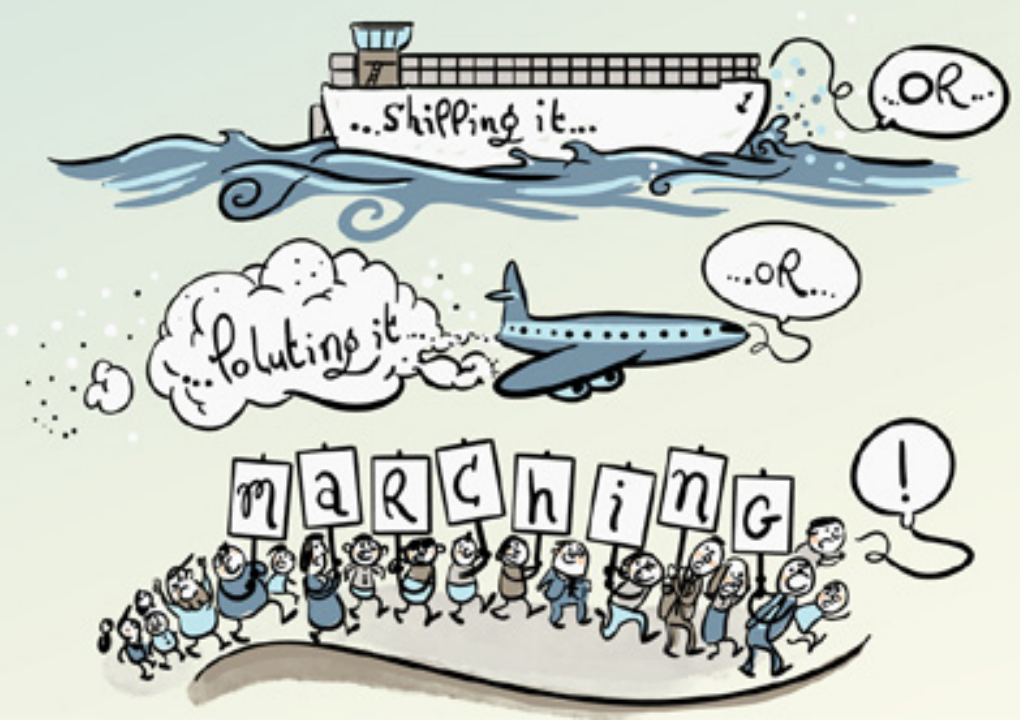

Globalisation as intensification

livelihoods of those fishermen (Miller et al., 2014). Such models are replicated in other food sectors, such as palm oil, coffee, soy and beef (Oosterveer, 2007), but also with regards to pollutive flows of ocean plastics and global transport flows such as shipping (Wuisan et al., 2012). Not only are these environmental flows intensifying but also the social practices, institutions and relations seeking to 'green' these flows.

Third, we are witnessing the acceleration of systematised transboundary interactions related to the environment. The mobility of environmental flows continues to accelerate year-on-year. Take resource trade, which has increased dramatically in pace over the last 30 years. It takes less than 35 days for a loin of tuna to travel from Indonesia to the shelves of Albert Heijn in Wageningen. It is not only the fish that are moving, but also fishers and information on their practices. This has led to the emergence of what some label hyper-globalisation linked to the rise of the digital economy (Castells, 2000; Rodrik, 2011). For example, we are currently seeing the emergence of new entrants in tuna governance, including Drone operators, satellite company and tech giants (see Toonen and Bush, 2018). The most prominent example is Global Fishing Watch, a partnership between Google, the NGO Oceana and the mapping company Skytruth with funding from the Hollywood star Leonardo de 
Caprio. The goal of this private organisation is to build a global, real-time surveillance system to monitor and dictate to states the extent of illegal fishing activity within and outside their jurisdictions. In fact, you too have the option of signing up and monitoring illegal activity right from your mobile phone.

Similar, but perhaps lower profile initiatives are evident in a wider range of urban environmental monitoring related to air quality and waste, as well as a range of SMART home energy and water systems (van Vliet, 2012; Naus et al., 2014). While the use of such platforms may be local in nature, the data they generate feed into global estimates and models of energy and climate.

Finally, we are seeing a continued deepening enmeshment of the local and the global. This dimension reminds us that environmental globalisation is not abstracted from everyday life. It is instead grounded in the practices of people in specific places, in specific ways and with specific social consequences. This deepening enmeshment is not just associated with cosmopolitan institutions, like the United Nations or WWF, but also with local actors and practices. As argued by Beck and colleagues (2013), it can also be seen in the convergence of experiences between these cosmopolitan and

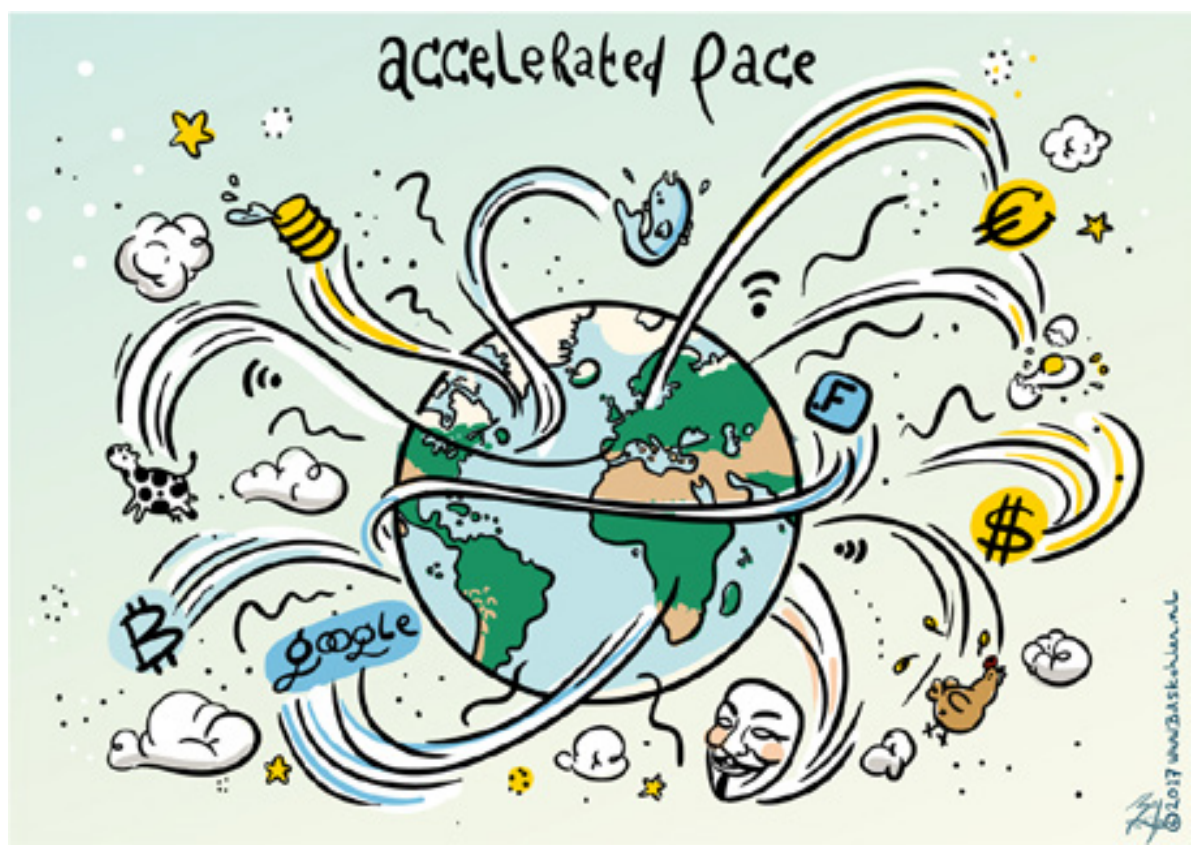

Globalisation as acceleration 
local actors in regards to environmental impacts which can stimulate shared responses. As research on the global sustainable seafood movement shows, the concern over the state of fish stocks and aquaculture production has led to various and unexpected coalitions of actors. For example, the exposure of seafood slavery driven in part by fishery decline in Thailand and Indonesia has led to the emergence of retail and NGO-led networks extending from these countries to New Zealand, the US, and even the Netherlands (Marschke and Vandergeest, 2016). These networks not only illustrate a shared concern over fisheries decline and bonded labour, but also the capacity of public and private actors to cooperate in seeking short term solutions.

But it is also evident from this research that these transnational networks lead to the reformulation of power relations. While so called 'global' concerns around stock decline may be met, local environmental problems and therefore communities can at the same time be co-opted. For example, the framing of illegal, unregulated and unreported or I-U-U fishing by the EU has had considerable impact on policing global fisheries (Agnew et al., 2009). But the definition of what constitutes illegal and unregulated is not shared by all countries and fishing communities alike (Bush and Marschke, 2016). The challenge under such circumstances is to understand the

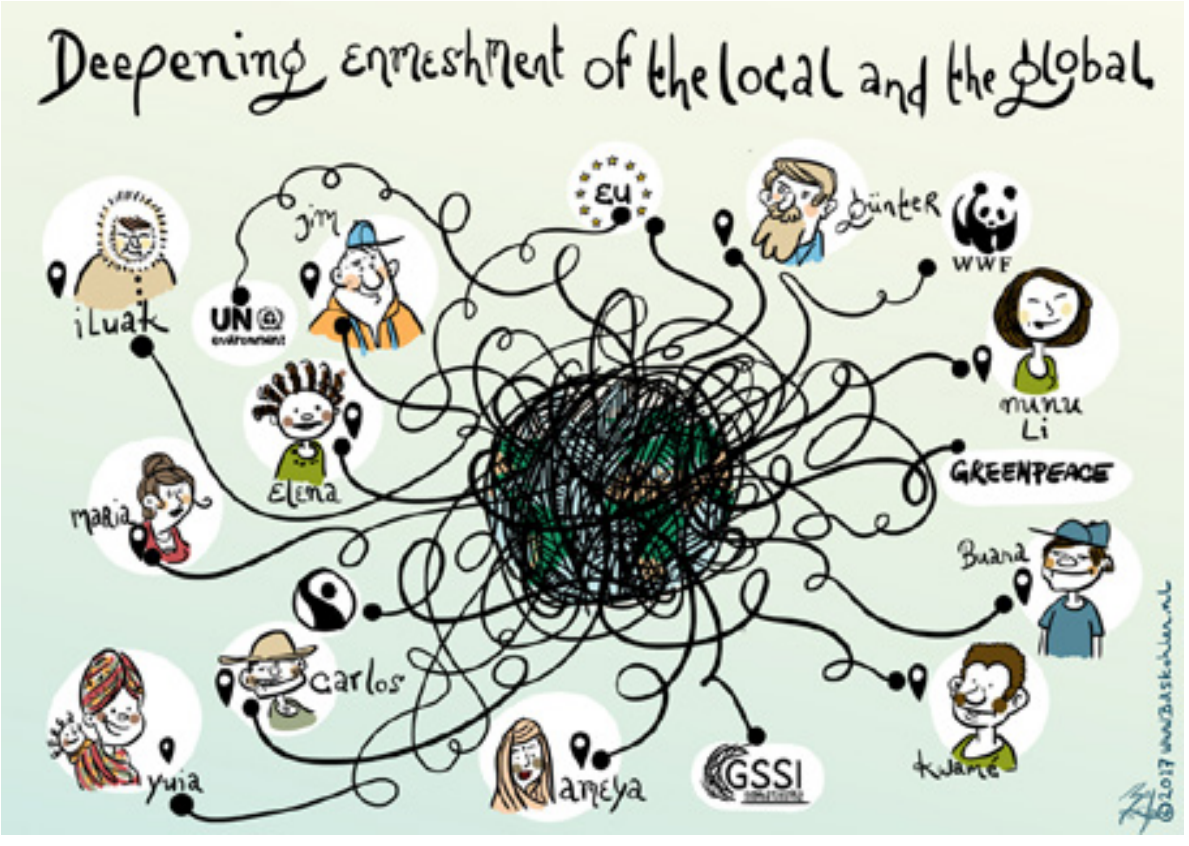

Globalisation as enmeshment 
dilemmas created by global-local connections and seek institutional arrangements that can most effectively lead to socially mediated environmental improvement.

For many of you these characterisations of globalisation will not be new. But given the social embedding of global connectivity in our world today there remains a pressing need to understand the extent to which the environment is shaped by globalisation, just as globalisation is shaped by environmental dynamics and concerns. Some may disagree and see 'environmental globalisation' as an oxymoron, two sides of an irretrievable debate around degradation and inequality. I instead prefer to see it as the interplay between material and social phenomena, which when taken together can enable cosmopolitan and locally embedded societies to reflexively contribute to modernisation and transformation in our 'age of environment'.

\section{Towards a more inclusive and reflexive form of environmental globalization}

The key challenge that will continue to structure my research and the research of the environmental policy group is the development of a theoretically informed understanding of inclusive and reflexive forms of environmental globalisation. The first step to achieving this, as I have already outlined, is to move beyond a narrow understanding of globalisation as neoliberal globalism. Second, as I have also outlined, we need to recognise and understand environmental globalisation as a social mediated set of processes. But third, and perhaps most importantly, I argue social scientists have to understand and contribute to the redesign of practices, institutions and relations that reflexively contribute to inclusive and effective forms of environmental governance.

Key to this is reflexive modernisation, which refers to the constant re-examining and reshaping of social practices and relations in light of incoming information about those very practices (Giddens, 1990). The result is a break from dogma and tradition and the "self-confrontation with the effects of risk society that cannot be dealt with and assimilated in the system of industrial society" (Beck et al., 1994, p. 6). Reflexive modernisation is therefore radical in that it opens up the possibility to break from business-as-usual and seek innovation in terms of new practices of production, trade and consumption. Signalling a break from simple modernity, it also denotes a shift away from the rational ordering of society and natural environments (Mol, 2001). It instead opens up the possibility to respond to failure, seek alternatives, and respond to anxieties of environment or economic inequality by designing new institutional arrangements that either reverse ongoing patterns of exploitation or deal with future environmental risks. 


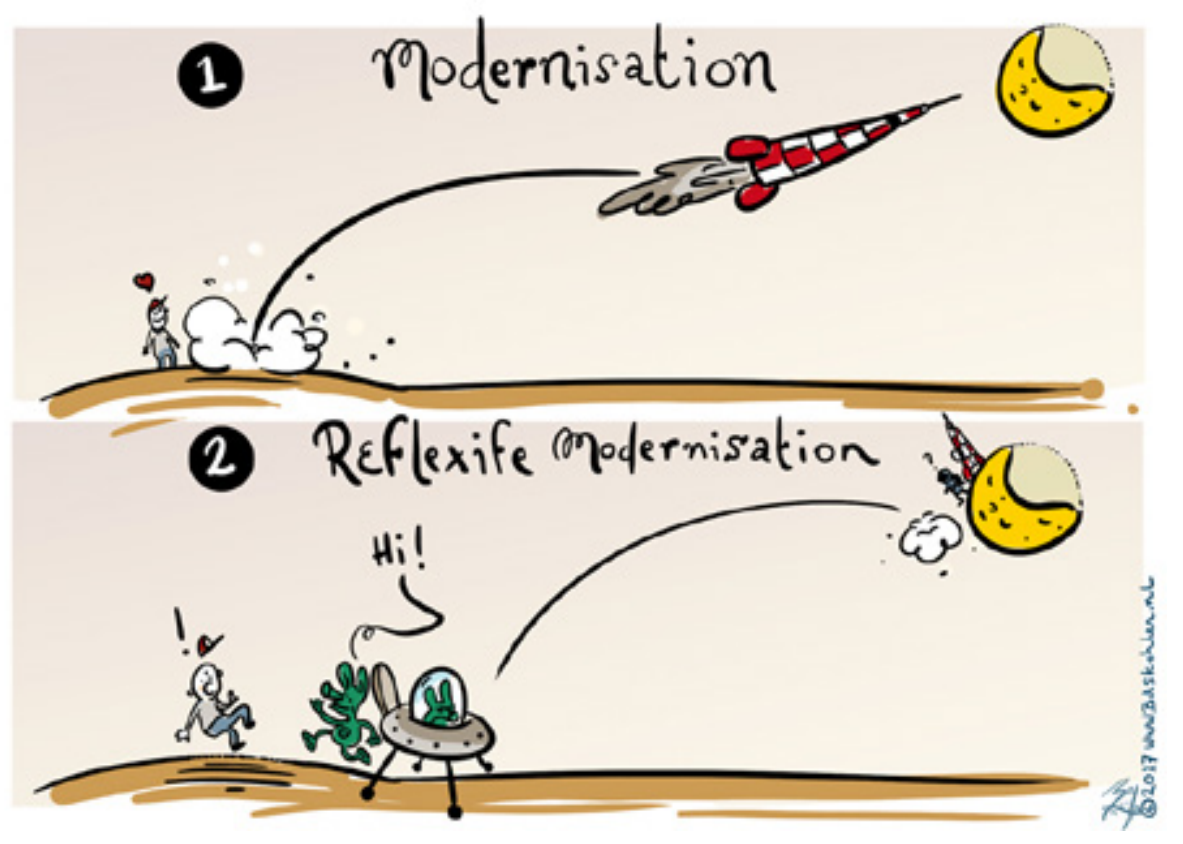

Reflexive modernisation

But a core critique of reflexive modernisation is its Western bias. Reflexivity is fine if one has the means to be reflexive. Under conditions of globalisation what this essentially means is that we need to understand who has the capabilities to internalise information, and in doing so, make changes to environmental practices, institutions and relations (see for example Toonen and van Tatenhove, 2013; Gupta and Mason, 2014; Bush et al., 2017). Are there cultural factors that enable or inhibit the uptake of environmentally friendly practices? Are such changes limited by wealth or education? To what extent does routine and technology play a role? These questions all point to the need for an understanding of inclusive modes of reflexive modernisation moving forward.

Indeed the need for globally inclusive reflexive modernisation will become ever more important given increased stretching, intensity, acceleration and enmeshment of social relations that emerge in response to shared environmental experiences and events (Christoff and Eckersley, 2013). It leads to questions on current governance arrangements and opens up the possibility for their re-design. For instance, can global market institutions like carbon markets, debt-for-nature swaps, or payments for ecosystem services be designed in way that facilitate reflexive rather than 


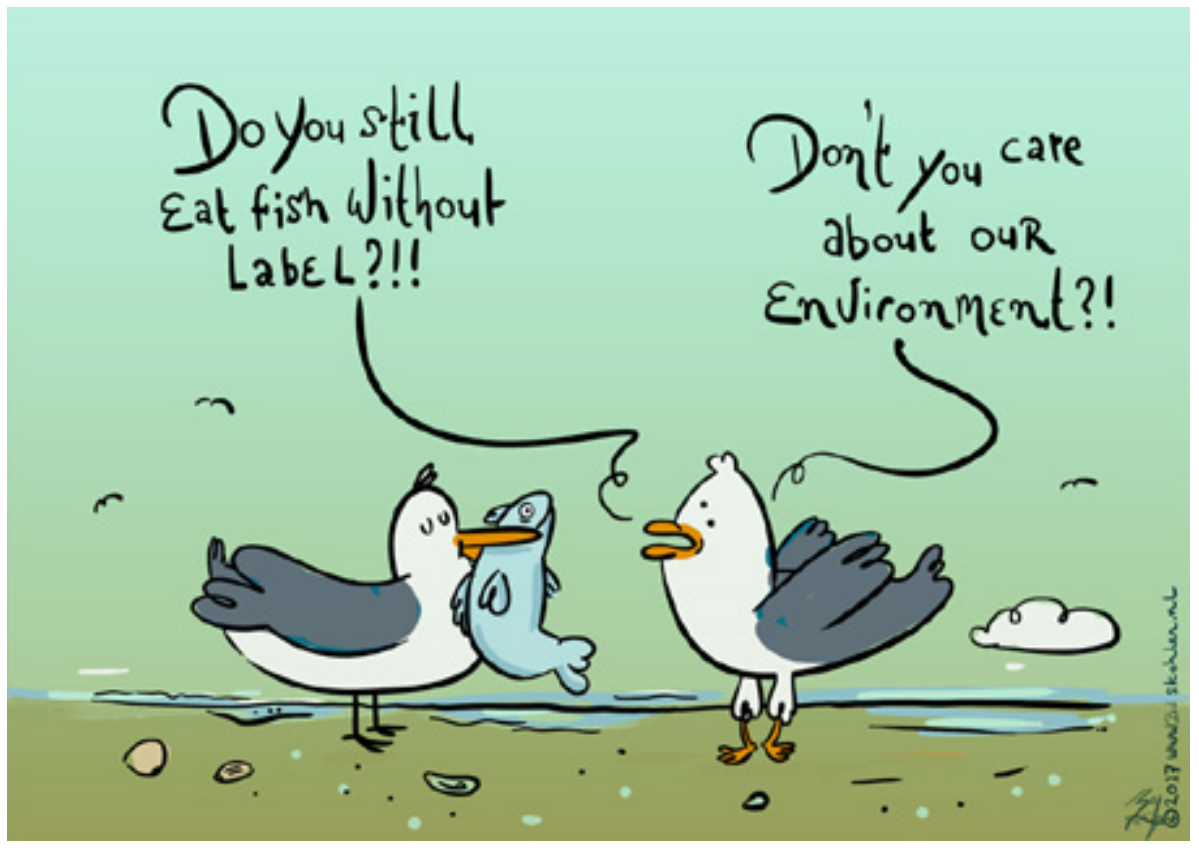

Inclusive reflexivity

transactional interactions across global space? Can global environmental treaties foster feedback and learning between countries rather than setting blanket regulation? And can positive local experiences be communicated effectively across language, cultures, ethnicity and social class?

In short, can we design environmental governance arrangements that can not only cope with the pace of globalisation, but also facilitate learning and change across and between global and local communities?

In order to answer these questions we need a greater understanding of how both cosmopolitan and local populations are able to question the ability of existing institutions to foresee and mitigate current and future environmental problems (Mol, 2008). For example, we can seek better understandings of how sustainable consumerism can lead to material environmental benefits, not only in the Netherlands, but also downtown Jakarta, Beijing, Bangkok or Nairobi (Spaargaren, 2011; Thongplew et al., 2014; Liu et al., 2016). We can also explore what political space there is for local participation in advocacy coalitions - again not only in Western Democracies, but also in single party states like Vietnam and China. 
Finally, we can research how small and medium enterprises can contribute to the greening of production and trade. Again, this not only means for SMART energy in Amsterdam, but also for palm oil in Malaysia or coastal fishing communities in Columbia. We also need to understand the anxieties of different societal groups in various countries around the world who are questioning the legitimacy and effectiveness of existing institutions designed to steer environmental globalisation. Here again the role of information and expertise in environmental governance is key. As recent history demonstrates, information provision is a key driver of global environmental anxieties and scepticism which cannot be ignored. As environmental social scientists it is our job to reveal these anxieties, understand them and feed them back into institutional design.

\section{Research agenda}

This then brings me to outline the future research agenda of the environmental policy group at Wageningen. Under my tenure the group will continue to place a priority on theoretically informed analysis of social and political transformations of a globalised environment. Building on our existing strengths we will analyse how and to what extent environmental considerations become incorporated into and change modernisation and globalisation processes. In doing so we will actively contribute to the design of environmental governance arrangements that extend across spatial scales and institutional levels.

The research programme of the group will be built around three objectives. First, we will analyse transformations in local, national and global environmental governance arrangements, against the background of a rapidly changing cultural, political and economic global order. Second, we will explore how individuals, groups and organisations deal with and respond to the environmental risks and uncertainties that emerge as side effects of globalisation. Third, we will contribute to the institutionalisation of inclusive standards, requirements and criteria for sustainable production and consumption.

Over the medium term our research will be divided into five research themes. Our food theme explores the challenges of ongoing global population growth and distributive challenges of sustainable nutrition provisioning. Our urban theme focuses on the design and governance of sustainable urban infrastructures, exploring the dynamic nature of cities and their regional and global environmental footprint. Our mobilities theme focuses on the challenges of governing sustainable tourism, migration, transport flows. Our marine theme incorporates research on the governance of the single largest global environmental resource, exploring issues 


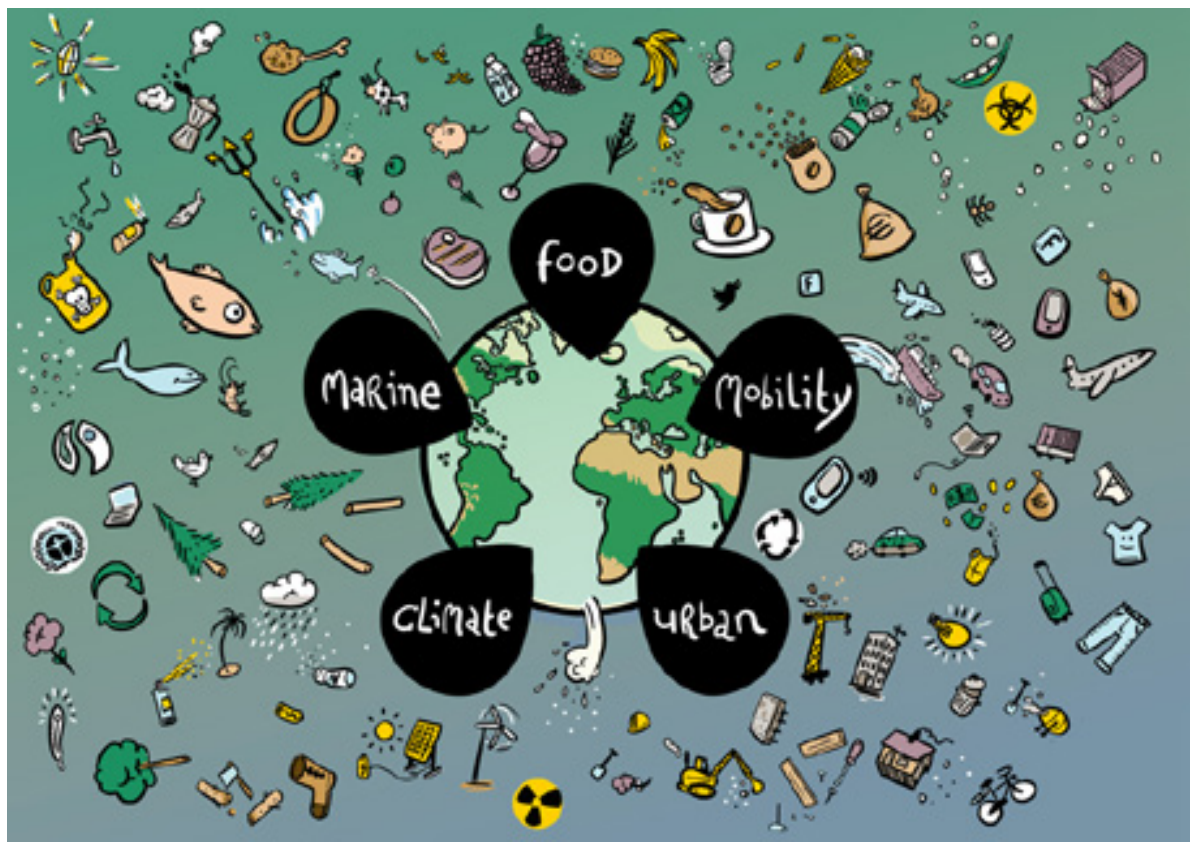

Research themes of the Environmental Policy Group

related to spatial planning, fisheries and offshore infrastructures. Finally our climate theme analyses both global and regional climate policies and their intersection with strategies for renewable energy provision.

Cutting across these objectives and themes are four interlinked sets of propositions that can contribute to the analysis of environmental globalisation.

First, environmental globalisation is a fundamentally political process that results from, as Newell argues, “deliberate actions and non-actions by political actors wielding political power ... [with] distributional impacts often derive[d] from the process by which decisions are made: who is represented, who participates, who makes policy, how and for whom?" (p. 4). This means we need to understand who is represented, who participates, who makes policy, how and for whom? Our research here will focus on understanding the extent to which public 'bads' emerging from globalisation, like poverty, inequality and environmental degradation, can be dealt with by the improved design of new arrangements. This will include questions on how to facilitate fairer and sustainable trade, increase transparency in decision making and improved representation of environmental issues in international forums like the European Union, United Nations and even World Trade Organisation 
(Stiglitz, 2007). In this same line, our research will question what kinds of policy arrangements (see Arts et al., 2000; Arts et al., 2006) within and beyond the state are best suited to providing credible, inclusive and effective forms of governance under conditions of environmental globalisation.

Second, environmental globalisation can be fruitfully analysed as a 'process from below', comprised of actors operating outside but often in partnership with the state. As already outlined, this requires exploring the potential of bottom up reflexive processes of environmental change. This might take many different forms, from the cosmopolitan social democracy (á la Held, 1995) to the constitution of a global network society (á la Castells, 2011). Here we are interested in new ways of understanding how market, state and civil society actors collaborate for the betterment of the environment. This requires research that goes beyond pigeon holing NGOs, companies and states into specific and fixed roles, and instead examines how they are 'dis-embedded' and 're-embedded' into new roles that reflect a common set of practices and objectives for addressing environmental issues (Beck, 2009). Our research will focus on understanding whether, how and what identities they might reflexively take on within the context of that issue, as well as the kinds of partnerships and 'hybrid' organisations that can emerge as a result.

Third, moving towards an environmental globalisation calls for reflexive and inclusive relationships between science and society. Here we must question who controls the definition of risk, and what forms of institutional arrangements emerge that allow us to anticipate and shape environmental change (Beck, 2009). In the context of global environmental information systems such a perspective is particularly poignant. Questions can start by asking who discloses environmental information. But as outlined by Gupta (2010) and Mol (2008), this also leads to questions of who defines information demands, who controls the data collected, and to what ends? Our research here will focus on understanding who controls the 'relations of definition' (e.g. de Krom and Oosterveer, 2010; Bush and Duijf, 2011). This in turn leads to a deeper understanding of the legitimacy and credibility of expertise in shaping the globalisation of political and social action around the environment through, for instance, the digital economy.

Finally, transformations through an environmental globalisation also requires understanding different socio-spatial configurations. This means that we are not only interested in the effects of state borders, but also in the formation of 'embedded boundaries' that exist both within and across the nation state (Sassen, 2006). For example, the emergence of 'sustainable territories' that are assembled by non-state environmental rules such as certification, eco-regions designated across international 
borders by states, or community conservation areas at the local scale (Vandergeest et al., 2015). In doing so we will focus on how the creation of these territories both include and exclude ecologies and actors, leading to either positive and negative sustainability outcomes.

\section{Conclusion}

In summary, social science is often quick to attest to the ills of globalisation, which as we will all recognise is a rich area of politics and scholarship at the present time. As research and the populist shift in Western democracies indicate, these ills are felt as real. Some also rightly question whether we are seeing a shift in the neoliberal order of Western democracies that has dominated the late $20^{\text {th }}$ century. Whether we are talking about tuna, climate change, arctic tourism, or clean energy, environmental globalisation will remain a policy and research imperative into the future. How governments, civil society, and corporations respond to this imperative will also play a role in shaping the emergence of a new economic and political global order.

In conclusion, the $21^{\text {st }}$ century will either see ecological catastrophe or ecological

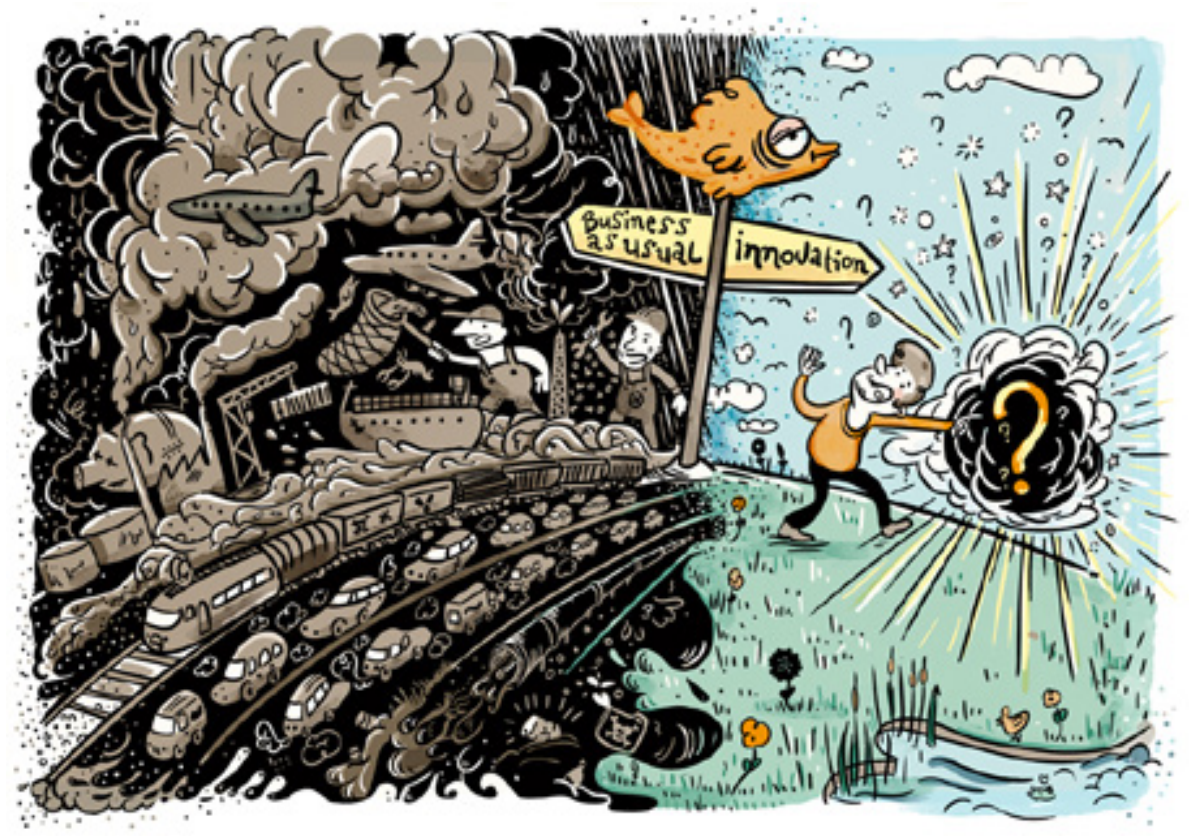

Towards innovation in the social sciences 
transformation (Sachs and Santarius, 2014). To steer society towards reflexive and socially inclusive outcomes we need effective governance arrangements that can proactively shape the conditions of global modernity. This then creates space for a new research agenda of understanding how reflexive and inclusive environmental globalisation can contribute to positive environmental change.

I am convinced that to realise this agenda social scientists need to move to transdisciplinary modes of science. This means partnering with societal actors to define and conduct our research. Such action is at the heart of the science of reflexive modernisation. Through these partnerships we should contribute to the co-design, and in many instances re-design, of institutional arrangements to reveal and deal with new and existing environmental problems.

I am equally convinced that as social scientists we shouldn't conduct this research alone. One of the key reasons I am still at Wageningen is the close partnerships I am able to build with my natural science colleagues. The very material elements of environmental globalisation provides rich territory to work in collaboration, be it on tuna, or any other global flow. Based on these partnerships I am convinced we can develop innovative insights and solutions. I can assure you the environmental policy group will continue to foster these connections.

Finally, I plan to be a strong advocate of the communication of social scientific research at Wageningen. Not only is such communication needed to report our results into society. It is also needed to foster interdisciplinary research. Gone are the days of a narrow academic publication culture. We need to adopt a publication-plus strategy that emphasises the role of our results as public goods for societal change. I hope the art work that has accompanied this lecture goes some way towards achieving that. We'll be working hard at ENP to keep the show going. 


\section{Word of thanks}

I would now like to take the opportunity to share some words of thanks.

First, I would like to thank Bas Kohler, the cartoonist that has helped me illustrate, and hopefully more effectively communicate this inaugural address. It was a fun experience to co-create some of the ideas and pictures.

My other thanks start by answering a question that I am very often asked. Why has an Australian stayed in the Netherlands for so long? There are in fact three answers.

The first is the combination of ENP and Wageningen University. On day one as an Assistant Professor at the Environmental Policy Group 12 years ago it was clearly apparent to me that the group, and indeed the university, was different. My colleagues had their doors open, walked into each other's offices and collaborated on all aspects of education and research. The strength and importance of 'the group' and the team science and education that embodies ENP was in sharp contrast to the traditional halls of silence I was accustomed to in other institutions. This was an academic culture that I wanted to stay a part of and one that I now have the pleasure to lead.

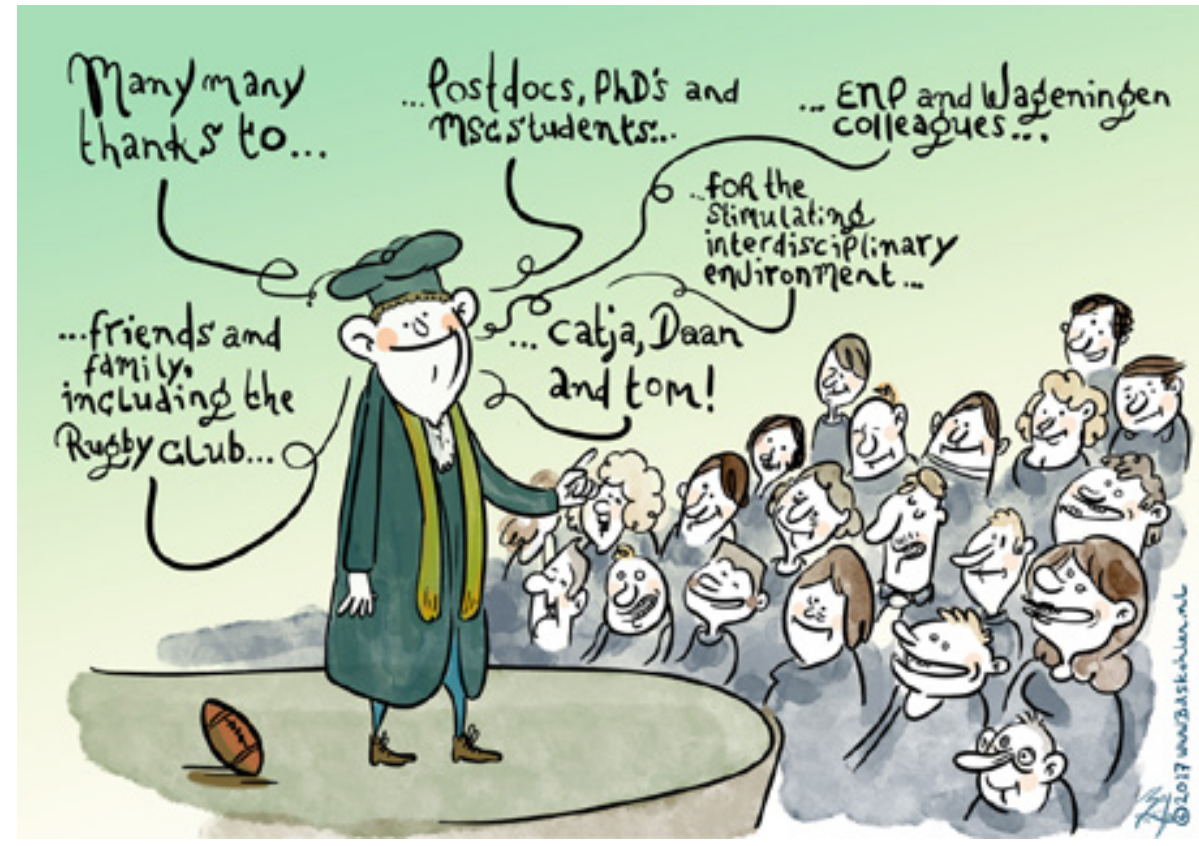

Word of thanks 
I want to thank my colleagues at ENP for providing me with a wonderful place to work, learn and grow. Your generosity of time, sharing ideas and putting up with the shortcomings of an Australian geographer interested in fish has been fundamental in shaping the course of my academic journey. As Chair of the group and Professor at this University I will strive to instil the same culture, generosity and stimulation to our young ambitious academics.

I also want to take the opportunity to thank my colleagues from around the University. Without the possibility to dive in and out of other disciplines my time here would have also been much shorter. In particular my colleagues at Public Administration, Forest and Nature Policy, Aquaculture and Fisheries, Marine Animal Ecology, Environmental Economics, and Environmental Systems Analysis to name but a few. I'd also like to individually thank my close colleague and friend Paul van Zwieten with whom I've travelled the world on shared tuna adventures. I look forward to continue collaborating with you all into the future.

Central to my Wageningen upbringing have been three key mentors who have been fundamental in shaping my thinking over the last decade; Arthur Mol, Gert Spaargaren and Peter Oosterveer. All three have coached, encouraged and at times tolerated my ideas and ambitions. I thank all three of them for their academic support, one of them in particular for taking another job. And happily enough he is still my boss.

Also within ENP I would like to thank Corry Rothuizen for her unwavering support in organising my working life.

As with anyone who makes it to an inaugural lecture I owe a huge debt of gratitude to my Postdoc researchers, PhDs and MSc students. They have provided me so much inspiration and taught me so much over my career to date. Here special thanks goes to Megan Bailey, now Assistant Professor at Dalhousie University, for her unwavering support of crazy ideas, as well as also sharing tuna adventures, and teaching me how economists think. Many more are spread around the world to whom I'll have to transmit my thanks at this time by video-stream and later in person. In short, thank you for your patience and for your support.

The second reason I tell people I have stayed are the close friendships and family I have accumulated in the Netherlands. The Aussies and the Dutch are much the same. We share a similar entrepreneurial attitude, a sharpness of tongue, and an often cutting humour, without which I would feel even more of a foreigner in this land. I am also eternally grateful that in some small enclaves of this country there is a 
fondness of rugby, and that I managed to find it. Thank you one and all. The third and of course the most important reason I have stayed is for the love of my life Catja. I'd love our life together no matter where we lived. But it is fair to say that without you I have would have left a long time ago. Thank you for simply everything - but especially for putting up with me during the writing of this inaugural lecture. To my two little Aussie-Dutchmen, Daan and Tom, you guys are the best.

Ik heb gezegd 


\section{References}

Adolf, S., S. R. Bush \& S. Vellema (2016). Reinserting state agency in global value chains: The case of MSC certified skipjack tuna. Fisheries Researcb 182: 79-87.

Agnew, D. J., J. Pearce, G. Pramod, T. Peatman, R. Watson, J. R. Beddington \& T. J. Pitcher (2009). Estimating the worldwide extent of illegal fishing. Plos one 4(2): e4570.

Allen, R., J. Joseph \& D. Squires (2010). Conservation and management of transnational tuna fisheries. London, Wiley-Blackwell.

Anh, P. T., S. R. Bush, A. P. J. Mol \& C. Kroeze (2011). The Multi-Level Environmental Governance of Vietnamese Aquaculture: Global Certification, National Standards, Local Cooperatives. Journal of Environmental Policy \& Planning 13(4): 373-397.

Arts, B., P. Leroy \& J. Van Tatenhove (2006). Political modernisation and policy arrangements: a framework for understanding environmental policy change. Public organization review 6(2): 93-106.

Arts, B., J. van Tatenhove \& P. Leroy (2000). Policy arrangements. Political modernisation and the environment, Springer: 53-69.

Bailey, M., J. Flores, S. Pokajam \& U. R. Sumaila (2012). Towards better management of Coral Triangle tuna. Ocean \& Coastal Management 63(o): 30-42.

Beck, U. (1992). Risk society: Towards a new modernity. London, Sage Publications.

Beck, U. (2009). World at risk, Polity.

Beck, U. (2015). What is globalization? Oxford, Polity Press.

Beck, U., A. Blok, D. Tyfield \& J. Y. Zhang (2013). Cosmopolitan communities of climate risk: Conceptual and empirical suggestions for a new research agenda. Global Networks 13(1): 1-21.

Beck, U., A. Giddens \& S. Lash (1994). Reflexive modernization: Politics, tradition and aesthetics in the modern social order, Stanford University Press.

Bernstein, S. (2002). The compromise of liberal environmentalism, Columbia University Press. 
Bush, S. \& M. Marschke (2016). Social and political ecology of fisheries and aquaculture in Southeast Asia. Routledge Handbook of the Environmental in Southeast Asia. P. Hirsch, Routledge: 224-238.

Bush, S. R., M. Bailey, P. van Zwieten, M. Kochen, B. Wiryawan, A. Doddema \& S. C. Mangunsong (2017). Private provision of public information in tuna fisheries. Marine Policy 77: 130-135.

Bush, S. R., B. Belton, D. Hall, P. Vandergeest, F. J. Murray, S. Ponte, P. Oosterveer, M. S. Islam, A. P. J. Mol, M. Hatanaka, F. Kruijssen, T. T. T. Ha, D. C. Little \& R. Kusumawati (2013). Certify Sustainable Aquaculture? Science 341(6150): 1067-1068.

Bush, S. R. \& M. Duijf (2011). Searching for (un)sustainabilty in pangasius aquaculture: A political economy of quality in European retail. Geoforum 42(2): 185-196.

Carter, N. T. \& A. P. Mol (2006). China and the environment: Domestic and transnational dynamics of a future hegemon. Environmental Politics 15(02): 330-344.

Castells, M. (1996). The Information Age: Economy, society and culture: Volume I. Oxford, Blackwell.

Castells, M. (2000). The rise of the network society. Oxford, Blackwell.

Castells, M. (2011). The rise of the network society: The information age: Economy, society, and culture, John Wiley \& Sons.

Christoff, P. \& R. Eckersley (2013). Globalization and the Environment, Rowman \& Littlefield Publishers.

Corbera, E., K. Brown \& W. N. Adger (2007). The equity and legitimacy of markets for ecosystem services. Development and change 38(4): 587-613.

Darnall, N. \& S. Sides (2008). Assessing the performance of voluntary environmental programs: does certification matter? Policy Studies Journal 36(1): 95-117.

de Krom, M. P. M. M. \& P. Oosterveer (2010). Contesting Risk and Responsibility: European Debates on Food and Agricultural Governance of Avian Influenza. Nature and Culture 5: 175-195. 
Duggan, D. E. \& M. Kochen (2016). Small in scale but big in potential: opportunities and challenges for fisheries certification of Indonesian small-scale tuna fisheries.

Marine Policy 67: 30-39.

Fairhead, J., M. Leach \& I. Scoones (2012). Green grabbing: a new appropriation of nature? Journal of Peasant Studies 39(2): 237-261.

Fukuyama, F. (1992). The End of History and the Last Man, Penguin.

Giddens, A. (1990). The Consequences of Modernity. Cambridge, Polity Press.

Gupta, A. (2010). Transparency in global environmental governance: a coming of age?, MIT Press.

Gupta, A. \& M. Mason (2014). Transparency in global environmental governance: Critical perspectives, MIT Press.

Ha, T. T. T. \& S. R. Bush (2010). Transformations of Vietnamese Shrimp Aquaculture Policy: Empirical Evidence From Ca Mau Province, The Mekong Delta. Environment and Planning C: Government and Policy 28(6): 1101-1119.

Ha, T. T. T., S. R. Bush, A. P. J. Mol \& H. Van Dijk (2012). Organic coasts? Regulatory challenges of certifying integrated shrimp-mangrove production systems in Vietnam. The Journal of Rural Studies 28: 631-639.

Havice, E. (2010). The structure of tuna access agreements in the Western and Central Pacific Ocean: Lessons for Vessel Day Scheme planning. Marine Policy 34(5): 979-987.

Havice, E. \& L. Campling (2017). Where Chain Governance and Environmental Governance Meet: Interfirm Strategies in the Canned Tuna Global Value Chain. Economic Geography 93(3): 292-313.

He, G., Y. Lu, A. P. Mol \& T. Beckers (2012). Changes and challenges: China's environmental management in transition. Environmental Development 3: 25-38.

Held, D. (1995). Democracy and the global order: From the modern state to cosmopolitan governance. California, Stanford University Press.

Held, D. \& A. McGrew (2007). Globalization/anti-globalization: Beyond the great divide, Polity. 
Liu, W., P. Oosterveer \& G. Spaargaren (2016). Promoting sustainable consumption in China: A conceptual framework and research review. Journal of Cleaner Production 134: 13-21.

Marschke, M. \& P. Vandergeest (2016). Slavery scandals: Unpacking labour challenges and policy responses within the off-shore fisheries sector. Marine Policy 68: $39-46$.

Miller, A. M., S. R. Bush \& A. P. Mol (2014). Power Europe: EU and the illegal, unreported and unregulated tuna fisheries regulation in the West and Central Pacific Ocean. Marine Policy 45: 138-145.

Miller, A. M. M. (2014). Governance Innovation Networks for Sustainable Tuna. Wageningen, Wageningen University and Research Centre. PhD.

Mol, A. P. (2001). Globalization and environmental reform: the ecological modernization of the global economy. Cambridge, MIT Press.

Mol, A. P. J. (2008). Environmental reform in the information age: the contours of informational governance. Cambridge, Cambridge University Press.

Mullon, C., P. Guillotreau, E. Galbraith, J. Fortilus, C. Chaboud, L. Bopp, O. Aumont \& D. Kaplan (2017). Exploring future scenarios for the global supply chain of tuna. Deep Sea Research Part II: Topical Studies in Oceanograpby 140: 251-267.

Naus, J., G. Spaargaren, B. J. van Vliet \& H. M. van der Horst (2014). Smart grids, information flows and emerging domestic energy practices. Energy Policy 68: 436-446.

Newell, P. (2012). Globalization and the Environment: Capitalism, Ecology and Power. Cambridge, Polity.

Newell, P. \& M. Paterson (2010). Climate capitalism: global warming and the transformation of the global economy, Cambridge University Press.

Oosterveer, P. (2007). Global governance of food production and consumption: issues and challenges, Edward Elgar Publishing.

Oosterveer, P. \& D. A. Sonnenfeld (2012). Food, globalization and sustainability, Routledge. 
Peet, R., P. Robbins \& M. Watts (2010). Global Political Ecology. London, Routledge.

Porter, M. E. (1990). The competitive advantage of nations. New York, Simon and Schuster.

Rodrik, D. (2011). The globalization paradox: why global markets, states, and democracy can't coexist, Oxford University Press.

Sachs, W. \& T. Santarius (2014). Fair future: resource conflicts, security and global justice. New York, Zed Books.

Sassen, S. (2006). Territory, Authority, Rights: From Medieval to Global Assemblages. Princeton, NJ, Princeton University Press.

Simpson, A. \& M. Smits (2018). Transitions to Energy and Climate Security in Southeast Asia? Civil Society Encounters with Illiberalism in Thailand and Myanmar. Society \& Natural Resources: 1-19.

Spaargaren, G. (2011). Theories of practices: Agency, technology, and culture: Exploring the relevance of practice theories for the governance of sustainable consumption practices in the new world-order. Global Environmental Change 21(3): 813-822.

Steffen, W., P. J. Crutzen \& J. R. McNeill (2007). The Anthropocene: are humans now overwhelming the great forces of nature. AMBIO: A Journal of the Human Environment 36(8): 614-621.

Stiglitz, J. E. (2007). Making globalization work, WW Norton \& Company.

Thongplew, N., G. Spaargaren \& C. Van Koppen (2014). Greening consumption at the retail outlet: the case of the Thai appliance industry. International Journal of Sustainable Development \& World Ecology 21(2): 99-110.

Thongplew, N., C. K. van Koppen \& G. Spaargaren (2016). Transformation of the dairy industry toward sustainability: The case of the organic dairy industries in the Netherlands and Thailand. Environmental Development 17: 6-20.

Tolentino-Zondervan, F., P. Berentsen, S. Bush, J. Idemne, R. Babaran \& A. O. Lansink (2016). Comparison of Private Incentive Mechanisms for Improving Sustainability of Filipino Tuna Fisheries. World Development 83: 264-279. 
Toonen, H. \& S. R. Bush (2018). The digital frontiers of fisheries governance: fish attraction devices, drones and satellites. Journal of Environmental Policy \& Planning.

Toonen, H. M. \& J. P. van Tatenhove (2013). Marine scaping: The structuring of marine practices. Ocean \& coastal management 75: 43-52.

Turnhout, E. \& S. Boonman-Berson (2011). Databases, scaling practices, and the globalization of biodiversity. Ecology and Society 16(1).

van Bets, L. K., M. A. Lamers \& J. P. van Tatenhove (2016). Governing cruise tourism at Bonaire: a networks and flows approach. Mobilities: 1-16.

van Vliet, B. J. (2012). Sustainable innovation in network-bound systems: implications for the consumption of water, waste water and electricity services. Journal of Environmental Policy \& Planning 14(3): 263-278.

Vandergeest, P., S. Ponte \& S. Bush (2015). Assembling sustainable territories: space, subjects, objects, and expertise in seafood certification. Environment and Planning a 47(9): 1907-1925.

Vijge, M. J. \& A. Gupta (2014). Framing REDD+ in India: Carbonizing and centralizing Indian forest governance? Environmental Science \& Policy 38: 17-27.

Wuisan, L., J. van Leeuwen \& C. K. van Koppen (2012). Greening international shipping through private governance: A case study of the Clean Shipping Project. Marine Policy 36(1): 165-173. 



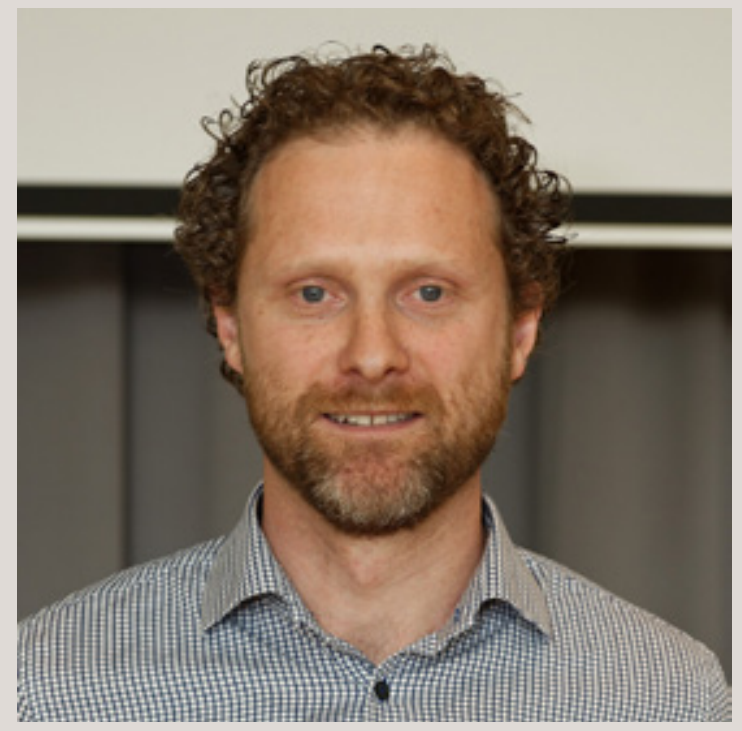

Prof.dr Simon R. Bush

Overcoming the environmental challenges of the next century requires new modes of globalisation. To contribute, social scientists need to move beyond a constraining focus on the ills of 'neoliberal capitalism'. Instead we need to understand how environmental reform can be achieved through the design of reflexive practices, relations and institutions that contribute to socially inclusive environmental reform under conditions of global modernity. 